\title{
積雪層モデルによる地上積雪重量のリアルタイム推定 REAL-TIME ESTIMATION OF GROUND SNOW LOAD USING SNOW LAYER MODEL
}

\author{
込山 大*1, バトスーリアシドマー*2, 高橋＼cjkstart徹*3 \\ Dai KOMIYAMA, Ashidmaa BATSUURI and Toru TAKAHASHI
}

\begin{abstract}
We proposed a real-time estimation model based on model to get a handle on the snow weight that changes by 1-hour step. In the real-time estimation, the hourly snow layer model and the optimized parameters for each location were newly introduced into the previous model. The optimized parameters for each location use the average of several years of winter optimized parameters obtained at each location.

We compared the estimated values obtained from the model with the measured data of Sapporo, Shinjo and Tokamachi. The estimated values were accurate in Tokamachi and Shinjo, but not so good in Sapporo.
\end{abstract}

Keywords : Real-time estimation, Snow Weight, Snow layer, Optimazed parameter リアルタイム推定, 積雪重量, 積雪層, 最適化パラメータ

\section{1. はじめに}

鉄骨大スパン構造物のように屋根の固定荷重が相対的に小さい場 合、断面算定において、雪荷重が支配的となるため、その設定を的 確に行うことが重要である。

屋根雪荷重の算定方法として建築物荷重指針・同解説（以後、荷 重指針）では、以下の式を示している ${ }^{1)}$

$$
\mathrm{S}=\mu_{0} S_{0}
$$

ここで、 $\mu_{0}$ は屋根形状係数， $S_{0}$ は地上積雪重量である。したがっ て屋根雪荷重を算定するためには地上積雪重量が重要となる。

これまで地上積雪重量の推定方法として、桜井・城ら ${ }^{213)}$ 及び上村・ 梅村ら ${ }^{45)}$ (6) は積雪重量の積算值から Degree-Day 法により求める融 雪量を減じる手法の提案、高橋らは積雪の各層ごとに積雪重量およ び単位体積重量を算定して層厚を求め、実測の積雪深との誤差が最 小となるパラメータを求める積雪層モデル (以後、高橋モデル) 7)879) の提案、また平島らは詳細な積雪の層構造を計算する積雪変質モデ

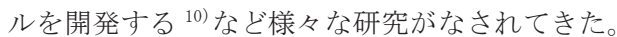

城・桜井ら及び上村・梅村らの方法では、断面観測がされていない 地点の融雪係数が示されていないこと、平島らの方法では、入力デ ータが多く、公式サイトから簡単に手に入る AMeDAS 観測データ のみで解析ができないという問題がある。他方、高橋モデルは AMeDAS から入手可能な 5 項目のデータで高精度に解析できる。 当該モデル提案当時の日データとしては、9 時の積雪深が公開され ていたが、現状は日最大積雪深となっており、夜中に降雪があって、 その上に降雨があり沈降したりすると、前日の 24 時の積雪深と当 日の 1 時の積雪深が最大積雪深として記録されることが起こり得る。 そこで、本研究では高橋モデルを基に、より現時点での公開データ
と親和性の高い方法で地上積雪重量を推定する方法を提案し、観測 記録を用いてその精度を検証する。

\section{2. 観測記録}

\section{1 気象観測記録}

モデルの検証を行うためには積雪重量が観測されている場所であ ること、または断面観測の単位体積重量と積雪深から積雪重量を算 定できる必要がある。本稿ではその地点として、新潟県十日町市、 山形県新庄市、北海道札幌市を対象とした。解析期間は、十日町で は 1999/00 冬期から 2018/19 冬期までの 20 年間、新庄では 1998/99 冬期から 2017/18 冬期までの 20 年間、札幌では 2005/6 冬期から 2018/19 冬期までの 14 年間である。また気象デー夕は十日町では、 森林総合研究所十日町試験地から提供して頂いた観測記録を、新庄、 札幌では AMeDAS ${ }^{11)} の$ 観測記録を用いた。

\section{2 積雪重量記録}

解析対象地点である 3 地点ではそれぞれの場所で下記のように積 雪重量の計測および断面観測が行われている。

十日町の森林総合研究所十日町試験地及び新庄の雪水防災センタ ーではメタルウェファーにより積雪重量の観測が行われている 12) 13)。また札幌の北海道大学低温科学研究所では週 2 回の頻度で断 面観測が行われている ${ }^{14)}$ 。したがって検証には、十日町、新庄では メタルウェファーによる観測記録を、札幌では断面観測の単位体積 重量と積雪深から積雪重量を算定して用いた。

\footnotetext{
*1 西松建設 修士 (工学) (元·千葉大学 大学院生)

*2 千葉大学大学院融合理工学府 大学院生

Nishimatsu Construction Co., Ltd., M.Eng. (Former Grad. Student of Chiba Univ.)

3 千葉大学大学院工学研究院 教授·博士(工学)

Prof., Graduate School of Engineering, Chiba University, Dr.Eng.
} 


\section{3. 高橋モデル}

\section{1 解析方法}

高橋モデルは降雪モデル、圧密モデル、融雪モデルから構成され る積雪層モデルである。降雪が記録された日に積雪層を形成し、圧 密や融雪、降雨の浸透などを経て 1 日ごとの積雪重量を推定する。 入力データは、AMeDAS から入手可能な 1 冬期における雪の降り始め から消雪までの日平均気温、日降水量、積雪深、日降雪量である。 ただし風により捕捉損失した日降水量を補正する場合はさらに風速 が必要である。またこのモデルにおける仮定は 2 つであり、1つ目 は日平均気温が $2^{\circ} \mathrm{C}$ 以上の日は降雪が記録されていても積雪層を形 成せずに全て雨とすること、2 つ目は積雪層の最大単位体積重量を $4.9 \mathrm{kN} / \mathrm{m}^{3}$ とし、それ以降は融雪水や降雨は保持せずにさらに下の層 に浸透させることである。解析では最小単位体積重量と融雪係数を 未知数として解析をはじめ、推定積雪深と実測積雪深の誤差が最も 小さくなる 1 冬期に 1 つの組合せ（以後、冬期最適化パラメータ） をプログラムのアルゴリズムの 1 つである最急降下法を用いて求め る。このときの誤差は次式に示すような、誤差の平均值を表す RMSE を用いる。

$$
R M S E=\sqrt{\frac{1}{N} \sum\left(x_{i}-\widehat{x}_{l}\right)^{2}}
$$

ここで、RMSE は積雪深の二乗平均平方根誤差，Nはデータの総数， $x_{i}$ は $i$ 日の積雪深推定値 $[\mathrm{m}], \widehat{x_{i}}$ は $i$ 日の積雪深観測值 $[\mathrm{m}]$ である。

\section{2 降雪モデル}

降雪時に形成される積雪層の初期単位体積重量は日平均気温 $\mathrm{T}$ を用いて次式から求める。

$$
{ }_{m} \rho_{0}= \begin{cases}\rho_{\text {min }} & \left(T \leq 0^{\circ} \mathrm{C}\right) \\ \rho_{\text {min }}+\frac{\rho_{\text {max }}-\rho_{\text {min }}}{3} \cdot T & \left(0^{\circ} \mathrm{C}<T \leq 3^{\circ} \mathrm{C}\right) \\ \rho_{\text {max }} & \left(3^{\circ} \mathrm{C}<T\right)\end{cases}
$$

ここで、 ${ }_{m} \rho_{0}$ は $m$ 層の降雪時単位体積重量 $\left[\mathrm{kN} / \mathrm{m}^{3}\right], \rho_{\min }$ は最小単 位体積重量 $\left[\mathrm{kN} / \mathrm{m}^{3}\right], \rho_{\max }$ は最大単位体積重量 $\left[\mathrm{kN} / \mathrm{m}^{3}\right]$ である。

\section{3 圧密モデル}

積雪層の圧密は、積雪層が形成された翌日から起こるものと考え 次式で求める。

$$
{ }_{m} \rho_{n}=\rho_{\min } \sqrt{n+{ }_{m} k}
$$

ここで、 ${ }_{m} \rho_{n}$ は降雪から $\mathrm{n}$ 日目の $\mathrm{m}$ 層の単位体積重量 $\left[\mathrm{kN} / \mathrm{m}^{3}\right], \mathrm{n}$ は層形成からの経過日数, ${ }_{m} k$ は補正日数である。また補正日数は、 積雪層形成時の単位体積重量が圧密過程において何日目に相当する かを表し、次式から求める。

$$
{ }_{m} k=\frac{\left({ }_{m} \rho_{0}\right)^{2}}{\left(\rho_{\min }\right)^{2}}
$$

\section{4 融雪モデル}

融雪量は、平均気温のみから融雪量を求める簡易法として知られ る Degree-Day 法を用い、次式から求める。

$$
W_{C}= \begin{cases}C_{m}\left(T-T_{0}\right) & \left(T_{0}<T\right) \\ 0 & \left(T \leq T_{0}\right)\end{cases}
$$

ここで、 $W_{C}$ は融雪量 $\left[\mathrm{N} / \mathrm{m}^{2}\right] ， \quad C_{m}$ は融雪係数 $\left[\mathrm{N} /\left(\mathrm{m}^{2}{ }^{\circ} \mathrm{C}\right)\right] ， T_{0}$ は融 雪下限気温 $\left[{ }^{\circ} \mathrm{C}\right]$ である。融雪下限気温は $-2{ }^{\circ} \mathrm{C}$ とている。また融雪 は降雪が観測された時、新たに形成された積雪層では起こらず、そ の下の層から起こるものとする。

\section{5 積雪深の算定法と浸透による単位体積重量の補正}

積雪層の重量は降水量から融雪分を除いた值（以後、水当量）で あるから、各層の積雪深は次式により求める。

$$
\begin{gathered}
{ }_{m} r=W_{\text {in }}-W_{\mathrm{C}} \\
{ }_{m} d_{n}=\frac{{ }_{m} r}{{ }_{m} \rho_{n}}
\end{gathered}
$$

ここで、 $W_{i n}$ は降水量、 ${ }_{m} d_{n}$ は降雪から $n$ 日目の $m$ 層の積雪深 $[\mathrm{m}]$, ${ }_{m} r$ は $m$ 層に含まれる水当量から換算した重量 $\left[\mathrm{kN} / \mathrm{m}^{2}\right]$ である。降雨 や融雪水が浸透するときは、積雪深を変化させずにその分単位体積 重量のみを増加させる。

\section{6 降水量の補正}

降水量は、測器において一定面積の受水口に入った降水を集め測 定される。このとき受水口付近の気流が乱され、降水の一部が測器 に捕捉されない捕捉損失という現象が生じることがある。横山らに よればこのときの捕捉率 $C R$ は次式で求められる ${ }^{15)}$ 。

$$
C R=\frac{1}{1+m U_{z}}
$$

ここで、CRは捕捉率， $m$ は測器ごとの係数， $U_{z}$ は受水口高さにお ける平均風速 $[\mathrm{m} / \mathrm{s}]$ である。このときの $U_{\mathrm{z}}$ は荷重指針により次式か ら求める。

$$
U_{Z}=U_{\mathrm{SDP}}\left(\frac{Z}{Z_{\mathrm{SDP}}}\right)^{\alpha_{\mathrm{SITE}}}
$$

ここで、 $U_{\mathrm{SDP}}$ は気象観測点の風速 $[\mathrm{m} / \mathrm{s}], Z$ は雨量計の受水口高さ $[\mathrm{m}], Z_{\mathrm{SDP}}$ は気象観測点の風速計高さ $[\mathrm{m}] ， \alpha_{\mathrm{SITE}}$ は地表面粗度区分 から決まる指数である。

本解析に用いた風速計高さと雨量計高さを Table1 に示す。機器の 高さは、新庄と札幌では気象庁から公開されている資料 ${ }^{17)}$ 及び Goog1e ストリートビューで確認して、十日町では十日町試験地の資 料 ${ }^{12)}$ をもとにそれぞれ決定した。また雨量計は 3 地点ともに溢水式 降水量計、地表面粗度区分はIII とした。ただし、十日町の 2009/10 冬期及び 2013/14 冬期は計器の不具合よるデータ欠損があったこと から転倒ます式雨量計で観測した值を用い、このときの雨量計高さ は $3.9 \mathrm{~m}$ とした。

Table1 Instrument height of each station measurement ${ }^{16)}$

\begin{tabular}{c|c|c}
\hline & $\begin{array}{c}\text { Anemometer height } \\
(\mathrm{m})\end{array}$ & $\begin{array}{c}\text { Rain gauge height } \\
(\mathrm{m})\end{array}$ \\
\hline Tokamachi & 10 & 3.5 \\
\hline Shinjo & 30.8 & 2.5 \\
\hline Sapporo & 59.5 & 2.5 \\
\hline
\end{tabular}




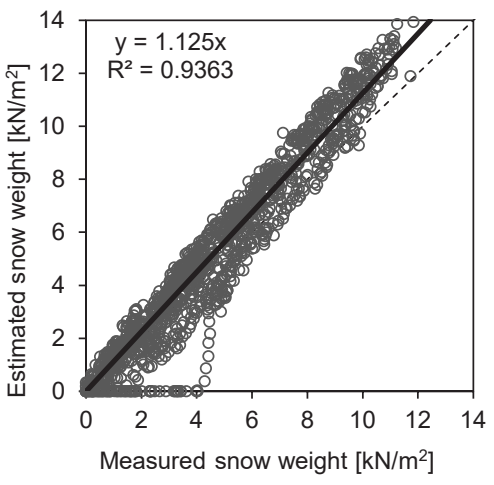

Fig.1 Analysis result of Daily snow layer model using corrected data in Tokamachi for 20 years

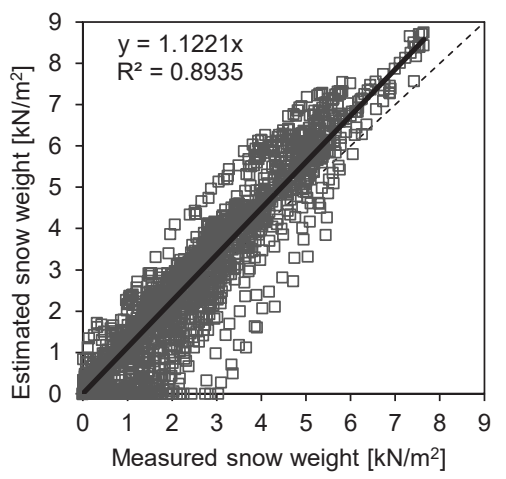

Fig.2 Analysis result of Daily snow layer model using corrected data in Shinjo for 20 years

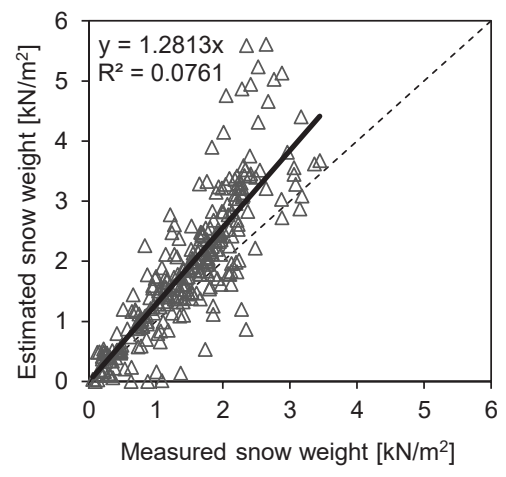

Fig.3 Analysis result of Daily snow layer model using corrected data in Sapporo for 10 years

\section{7 高橋モデルの推定結果}

高橋モデルを用いて 3 地点を解析し, 捕捉率補正を行った推定結 果を Fig.1〜Fig.3 に、捕捉率補正無しで行った解析結果を Fig.9, Fig.11, Fig.15に示す。推定值の精度検証は、推定の積雪重量と実測 の積雪重量から作成した散布図における回帰直線の傾きと決定係数 $\mathrm{R}^{2}$ を用いた。縦軸に推定積雪荷重、横軸に観測積雪荷重を取り、回 帰直線の傾きが 1 に近いほど精度が高いといえる。解析結果は図か ら分かるように、十日町と新庄では良好な結果を得ることができた。 しかし札幌では、傾きが大きく、またばらつきが大きい。その原因 としては、札幌は新庄と十日町と比べて積雪量が少なく、当モデル は積雪量が小さいと精度が低くなることが考えられるが、詳しくは 5 章で考察する。

3 地点ともに降水データをそのまま用いた解析に比べて、補正デ 一タによる解析は, 十日町では傾きが 1.0807 から 1.125 に、新庄で は傾きが 1.0545 から 1.1221 に、札幌では傾きが 1.1642 から 1.2813 に大きくなり、決定係数 $\mathrm{R}^{2}$ は小さくなっていることが分かる。

この結果より、高橋モデルでは捕捉率補正して解析を行うと積雪 重量が過大推定となり、ばらつきが大きくなることが分かった。今 後は補足率補正の式改善について検討が必要である。リアルタイム で推定するモデルでは、補足率補正をある条件のもとで使用したが、 詳しくは 4.4 節で述べる。

\section{4. リアルタイム推定モデル}

\section{1 積雪時の降水について}

高橋モデルは、降雪が記録された日に積雪層を形成し、その層に その日の降水を全て含むものである。しかしこの方法では過大な積 雪層を形成する可能性がある。例として新庄の AMeDAS における 2016 年 2 月 19 日の 1 時間毎の降水の観測記録を Fig.4 に示す。こ の日の 1 日毎の気象観測記録では平均気温が $-1.4^{\circ} \mathrm{C}$ 、降雪が $1 \mathrm{~cm}$ 、 降水量が $6.5 \mathrm{~mm}$ と記録されている。しかし積雪は 9 時に $1 \mathrm{~cm}$ 降っ たのみでこの時間の降水量はわずか $0.5 \mathrm{~mm}$ であった。したがって 1 時間毎の観測記録（以後、時間観測記録）では、残りの降水量 $6 \mathrm{~mm}$ は降雨として記録されているのにも関わらず、解析では全て雪とし て計算していることになる。このように 1 日毎に解析を行った場合、 降水を過剩に含む（モデルの上限である単位体積重量 $4.9 \mathrm{kN} / \mathrm{m}^{3}$ を 上回る）層が形成され過大推定となる場合があるため、解析には 1
日毎の気象観測記録を用いるのではなく、時間観測記録を用いるこ とで精度向上が期待できると考えられる。

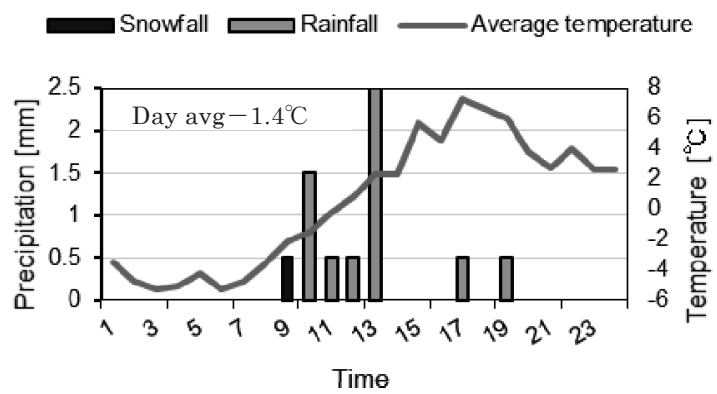

Fig.4 Precipitation record for February $19^{\text {th }}, 2016$ in Shinjo

\section{2 時間観測記録を用いた解析法}

時間観測記録を用いて解析を行うために新たに 1 時間毎の積雪層 である時間積雪層を導入した。この積雪層は (3) 式の降雪モデルを用 いて気温から降雪時の単位体積重量を求める。また時間積雪層はそ の日の 24 時に日積雪層に変化すると考えれば、その後の積雪層は 1 日毎の積雪層（以後、日積雪層）として扱うことができ、これまで の降雪モデル、圧密モデルをそのまま用いることが出来る。このと きの日積雪層の単位体積重量と時間積雪層の関係を次式に示す。

$$
{ }_{m} \rho_{n}=\frac{\sum_{h=1}^{24} r}{\sum_{h=1}^{24}{ }_{h} d}
$$

ここで、 ${ }_{n} r$ は $m$ 日のh層に含まれる累計降水量から換算した重量 $\left[\mathrm{kN} / \mathrm{m}^{2}\right],{ }_{h} d$ は $m$ 日のh層の累計積雪深 $[\mathrm{m}]$ である。時間積雪層は 1 時 間毎に形成され、最長でも 24 時間という短い時間で日積雪層に変 化すると考えることから圧密は考慮せず、融雪及び降水・融雪水の 浸透のみ考えるものとする。またこの手法における融雪モデルは、 1 時間毎の融雪量を求める Degree-hour 法を用いる。この方法で求 める融雪量は融雪係数の值のみ変わることから 1 時間毎の平均気温 を用いて(6)式から算定する。

\section{3 パラメータの設定方法}

これまで高橋モデルでは、推定積雪深と AMeDAS 観測積雪深の 誤差が最小となるように、未知の 2 つパラメータである、融雪係数 
と最小単位体積重量をその冬期に最適值で求めていた。しかし冬期 最適化パラメータを求めるためには、1 冬期の雪の降り始めから消 雪までの気象観測データが必要である。リアルタイム推定ではデー タがそろう前から解析を始めるため、あらかじめパラメータを設定 しておく必要がある。

本研究では、融雪係数と最小密度を既知パラメータとして、積雪 深と積雪重量を推定した。Fig.5 に新庄と十日町の 20 冬期分、札幌 の 14 冬期分の冬期最適化パラメータを示す。

地点ごとのパラメータがある程度固まっていることから、冬期に よらず、地点ごとに 1 つのパラメータの組合せが存在すると考える。 このパラメータは札幌と十日町での 20 冬期分、新庄の 35 冬期分の 解析を行い、平均值をその地点の最適なパラメータ (以降、地点最 適化パラメータ）として解析に用いる。3 地点における地点最適化 パラメータの值は Table2 にそれぞれ示す。

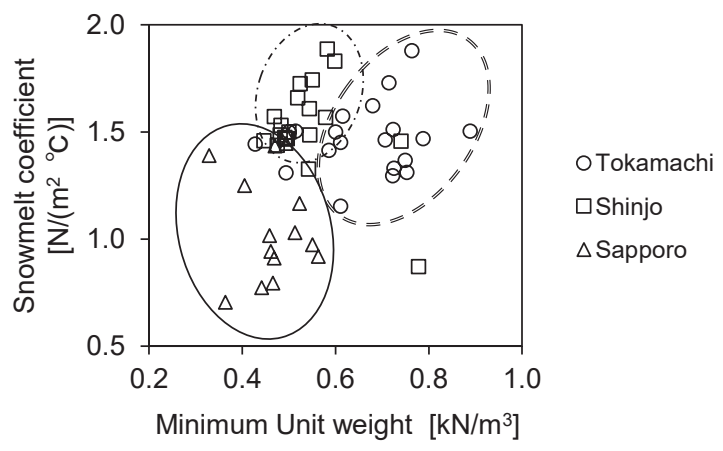

Fig.5 Winter optimal parameters for each location

Table2 Optimized parameter for each location

\begin{tabular}{c|c|c}
\hline & Unit weight $(\mathrm{kN} / \mathrm{m} 3)$ & $\begin{array}{c}\text { Snowmelt } \\
\text { coefficient } \\
\left(\mathrm{N} /\left(\mathrm{m} 2{ }^{\circ} \mathrm{C}\right)\right.\end{array}$ \\
\hline Tokamachi & 0.659 & 1.466 \\
\hline Shinjo & 0.542 & 1.528 \\
\hline Sapporo & 0.464 & 1.054 \\
\hline
\end{tabular}

\section{4 実測の積雪深による補正}

前節では、リアルタイム推定モデルにおうける地点最適化パラメー タの必要性を述べた。しかしこのパラメータの值が冬期最適化パラ メータとかけ離れている場合、積雪深の推定精度が悪くなり、それ に伴って積雪重量の推定結果も悪くなることが考えられる。

全国で積雪重量を測定しているところは少ないが積雪深を観測し ている AMeDAS 観測点は 323 か所ある。そこで、AMeDAS 観測デ ータのみで解析可能な高橋モデルの優位点を利用して Fig.6 に示す ように推定積雪深を AMeDAS 観測積雪深と比較することで補正を 行った。

3.7 節、高橋モデルの推定結果で述べた通り、降水量の補足率補 正を行うと積雪重量を過大推定する傾向にある。そのため、Fig.7の ように推定積雪深が過小となっている場合は、捕捉損失が起きてい ると考え、捕捉率補正をした降水を用いた。この補正により(8)式の 分子の ${ }_{n} r$ が増加され、積雪深及び積雪重量の推定値が高くなる。ま
た Fig.8 のように推定積雪深が過大推定となった場合は、最大単位 体積重量に達していない下の積雪層から実測の積雪深と同じ深さに なるまで強制的に圧密を行う。この補正では積雪深の推定精度が向 上寸るだけでなく、圧密によって単位体積重量が増加する。従って、 それ以降の融雪水や降雨の保持できる浸透量が減少する。これらの 補正を行うことで積雪重量の推定精度が向上すると考えられる。

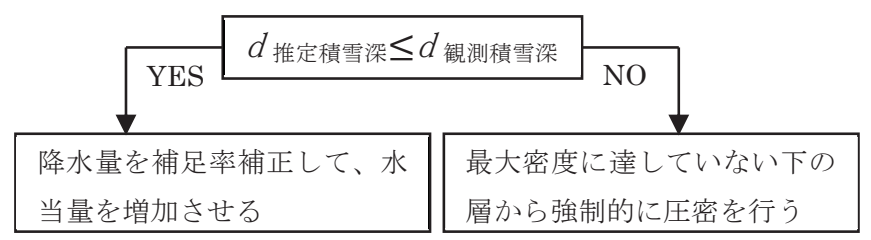

Fig.6 Condition on using correction

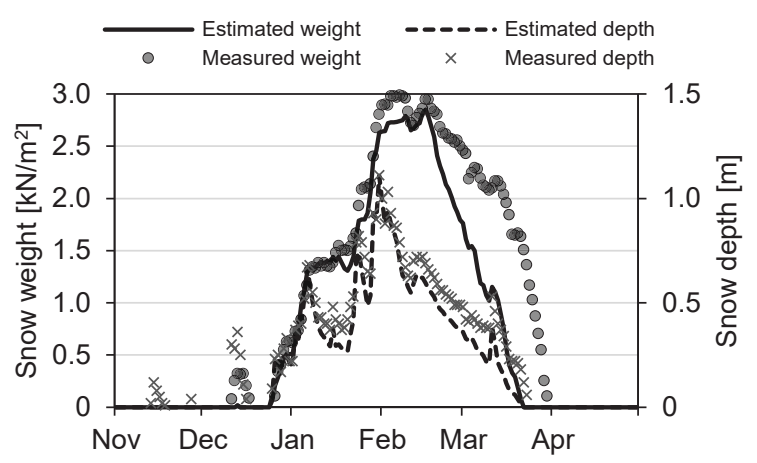

Fig.7 Example of underestimation when using optimized parameters for each location in Shinjo in 2002/03.

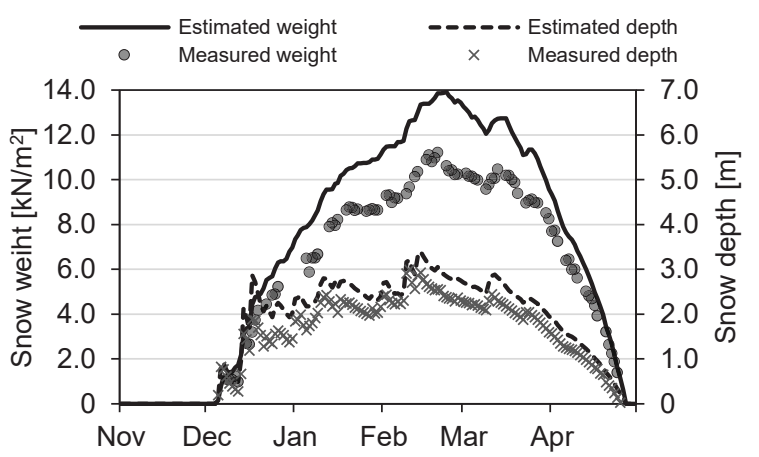

Fig. 8 Example of underestimation when using optimized parameters for each location in Tokamachi in 2014/15

\section{5. モデルの精度検証}

リアルタイム推定モデルで解析を行い、1 日ごとの推定積雪重 量を実測の積雪重量と比較、精度検証を行った。検証には、1 冬期 における積雪重量の推移、高橋モデルの検証と同様に推定の積雪重 量と実測の積雪重量から作成した散布図における回帰直線の傾きと 決定係数 $\mathrm{R}^{2}$ 、推定の最大積雪重量と実測の最大積雪重量の誤差の割 合と実測の最大積雪深から作成した散布図を用いた。

\section{1 十日町での推定結果}

Fig.9 には高橋モデルの推定結果を、Fig.10 にはリアルタイム推 定の結果を示す。図より全体的にリアルタイム推定で高橋モデルよ 


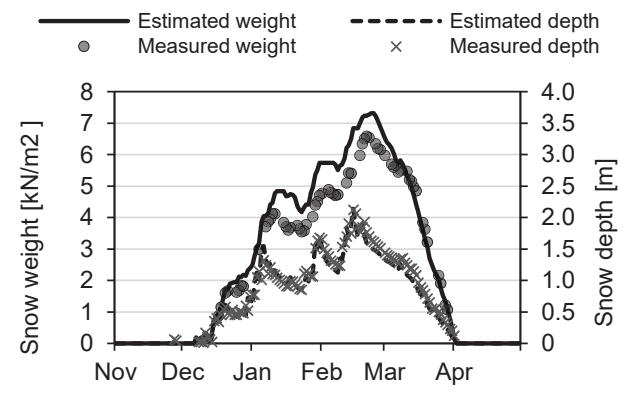

a. Snow weight and snow depth transition in $2001 / 02$

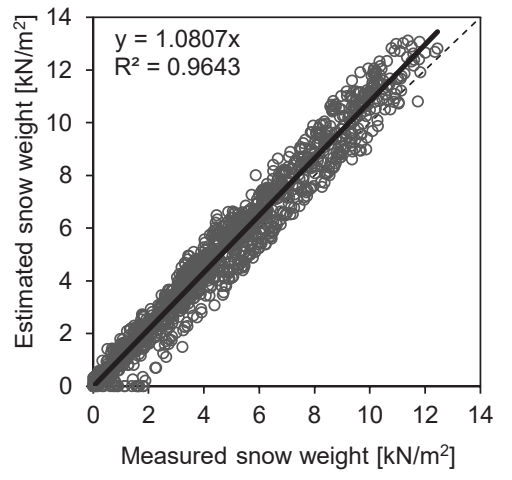

b. Comparison of Estimated weight and Measured weight of 20 years

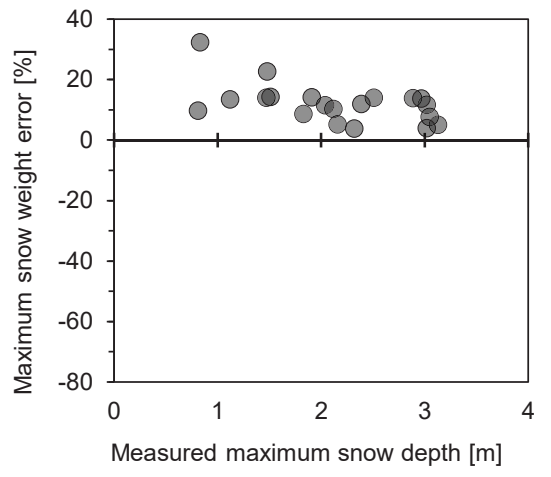

c. Max snow weight error and Measured max snow depth relation of 20 years

Fig.9 Analysis result of Daily snow layer model in Tokamachi

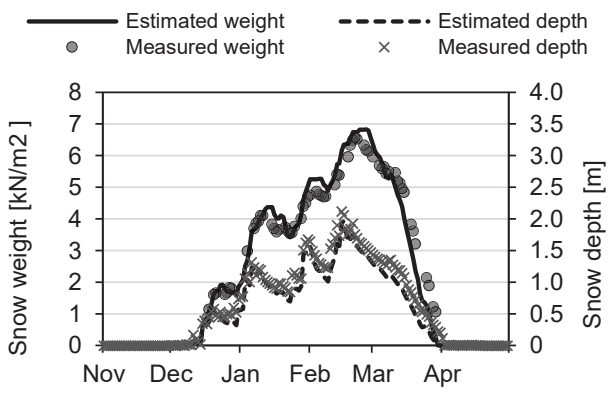

a. Snow weight and snow depth transition in $2001 / 02$

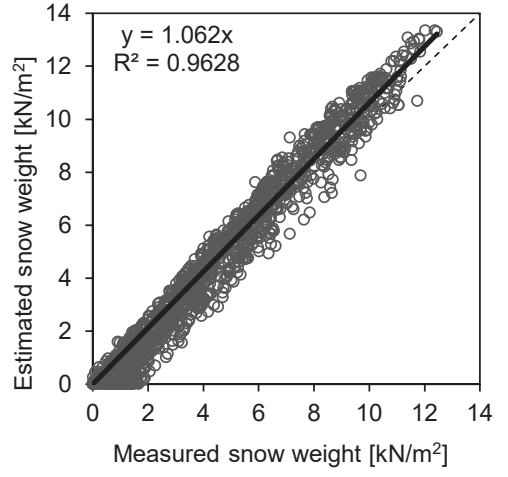

b. Comparison of Estimated weight and Measured weight of 20 years

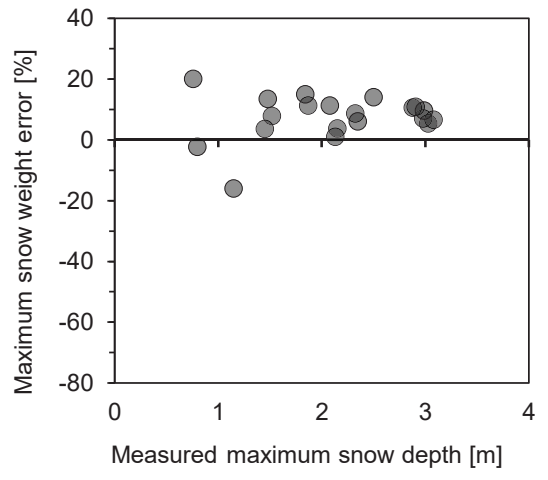

c. Max snow weight error and Measured max snow depth relation of 20 years

Fig.10 Analysis result of Hourly snow layer model in Tokamachi

り推定精度を上げることができたと言える。

Fig.9.a と Fig.10.a には 2001/02 冬期の雪の降り始めから消雪ま での積雪深及び積雪重量の推移を示す。図から分かるように、高橋 モデルでは、推定積雪重量が最大積雪重量に達する時期と観測值が 最大積雪重量に達する時期が一致するが、全体的に推定值は観測值 を上回る傾向にある。一方リアルタイム推定では、精度が高く推定 できており、その要因は時間観測記録を使用したことだと考えられ る。

Fig.9.b と Fig.10.b には縦軸に推定積雪重量、横軸に観測積雪重 量を取った、観測值と推定值の 20 年分の比較散布図を示す。実線と 破線が近く、回帰直線の傾きが 1 に近いほど精度が高いが、十日町 では傾きが 1.062 となり推定重量が観測積雪重量を上回る傾向にあ る。その一方、決定係数 $\mathrm{R}^{2}$ は解析を行った 3 地点の中で最も高く 0.9628 で、20 年間分の解析結果は全体的にばらつきが小さく、最も 精度がよかった。さらに高橋モデルと比較したところ、傾きが Fig.9.b と Fig.10.b から分かるように、1.0807から 1.062 に下がっ ており、20 年分全体的に過大推定していた結果の精度を上げた。

Fig.9.c と Fig.10.c に実測の最大積雪深に対する推定値と観測值 の最大積雪重量の誤差の関係を示す。誤差は次式によって計算した。

$$
\text { Error }=\left(1-\frac{W_{\text {m.max }}}{W_{\text {e.max }}}\right) \times 100
$$

ここで、 $W_{m \cdot \text { max }}$ は実測の最大積雪重量、 $W_{e . \text { max }}$ は推定值の最大積雪
重量である。散布は高橋モデルとリアルタイム推定が共に実測の積 雪深が小さくなるにつれて䛊差が大きくなる傾向にある。高橋モデ ルではすべての誤差がプラスの值で、0〜40\%の間であることから、 改めて過大評価していたことが証明された。Fig.10.c から、リアル タイム推定では、誤差はー15\%〜20\%の範囲内だった。

\section{2 新庄での推定結果}

Fig.11 には高橋モデルの推定結果を、Fig.12 にはリアルタイム推 定の結果を示寸。全体的に、十日町と同様に、リアルタイム推定で は高橋モデルより推定精度を上げることが出来た。Fig.11.a と Fig.12.a には 1998/99 冬期の雪の降り始めから消雪までの積雪深及 び積雪重量の推移を示す。図からわかるように、高橋モデルとリア ルタイム推定はともに、積雪期間に大きな融雪が起こると積雪重量 の急激な減少を推定できないことが分かる。（Fig.11.a と Fig.12.a の 1 月中旬からの積雪重量の推移を参照)。高橋モデルでは、推定 積雪重量が最大値に達する時期は観測值が最大積雪重量に達する時 期より早まっており、全体的に観測值より高い。その一方、リアル タイム推定は高橋モデルと同様に 1 月に起こった大きな融雪をうま く推定できていないにも関わらず、推定積雪重量が最大積雪重量に 達する時期とその值は観測值と一致している。Fig.11.b と Fig.12.b は縦軸に推定積雪重量、横軸に観測積雪重量を取った 20 年分の観 測值と推定值の比較分布図である。新庄では傾きが 3 地点の中で最 


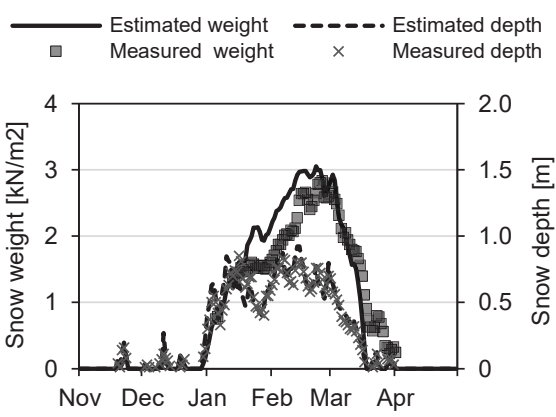

a. Snow weight and snow depth transition in 1998/99

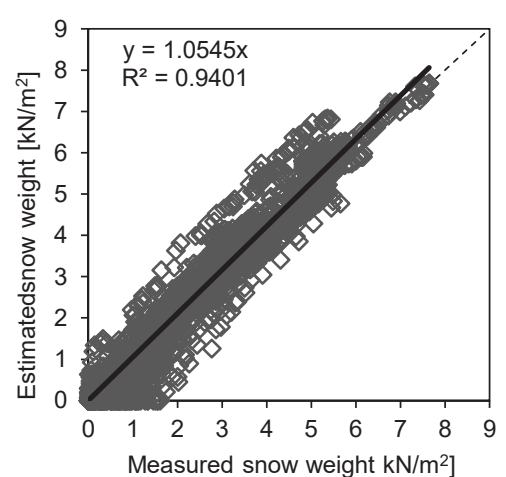

b. Comparison of Estimated weight and Measured weight of 20 years

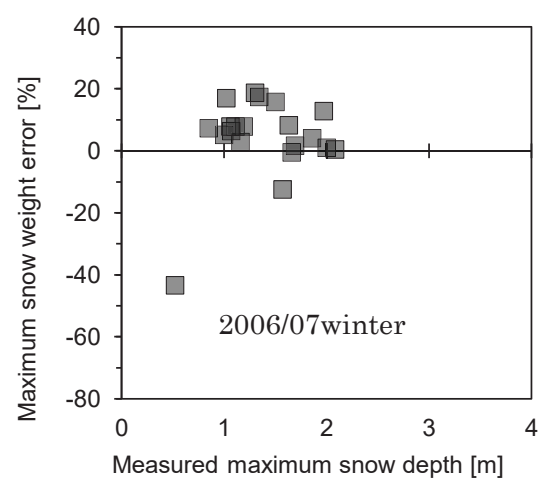

c. Max snow weight error and Measured max snow depth relation of 20 years

Fig.11 Analysis result of Daily snow layer model in Shinjo

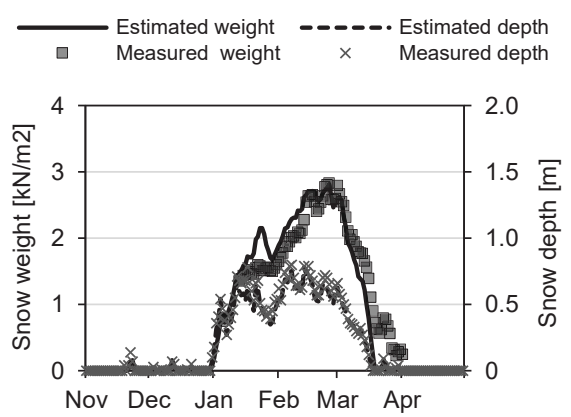

a. Snow weight and snow depth transition in 1998/99

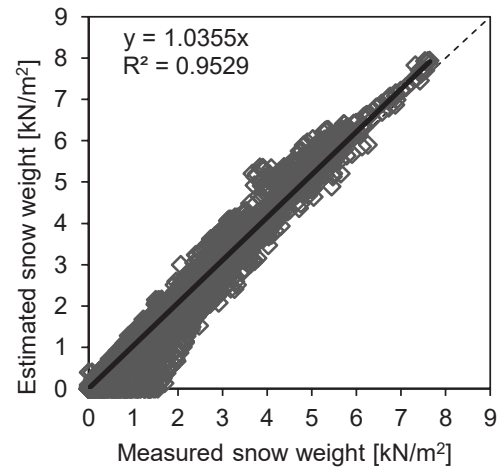

b. Comparison of Estimated weight and Measured weight of 20 years

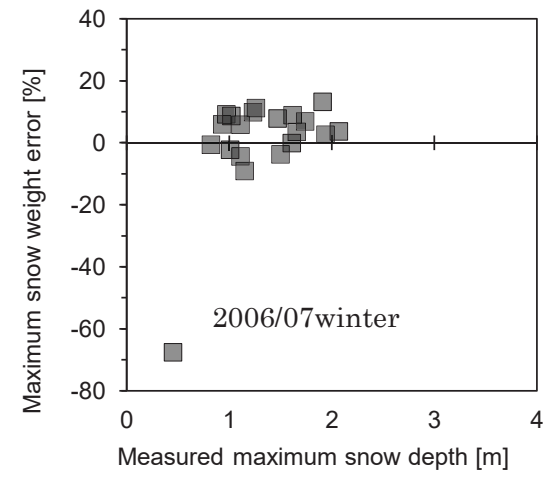

c. Max snow weight error and Measured max snow depth relation of 20 years

Fig.12 Analysis result of Hourly snow layer model in Shinjo

も 1 に近く 1.0355 となった。さらに決定係数 $\mathrm{R}^{2}$ は十日町より低い ものの 0.9529 と高く、精度がよかったと言える。その要因はFig. 5 から分かるように新庄での最適パラメータの固まりが一番小さく、 その冬期最適パラメータは地点最適化パラメータに近く、精度のよ い結果となったと考えられる。しかし、リアルタイム推定と高橋モ デルがともに、散布図の広がりから分かるように十日町と同様に積 雪重量が小さく $1 \sim 2 \mathrm{kN} / \mathrm{m}^{2}$ の時、推定值は観測值を下回る傾向が見 られ、積雪重量が重くなるにつれて観測值と推定值が一致している。 全体的には高橋モデルの過大推定する傾向を観測值に近づけ、ば らつきを小さくさせ、推定の精度を上げることができた。その要因 としては 4.1 節でも述べたように、時間観測記録を用いたことで雨 雪判別が明確になったことが考えられる。

Fig.11.c と Fig.12.cには 20 年分の実測の最大積雪深に対寸る推 定值と観測值の最大積雪重量の誤差の関係を示す。新庄では、高橋 モデルとリアルタイム推定の 2006/07 冬期の誤差は、非常に大きく、 それ以外ではリアルタイム推定はー5〜 15\%の範囲内で納まり、ばら つきが少なく、十日町の場合と違ってマイナスの誤差が出る場合も 多い。さらに、高橋モデルの誤差はばらついているのに対して、リ アルタイム推定は誤差の範囲が狭く、積雪量が多い年でも良い精度 で推定をしている。

2006 年度冬期は降雪が少なく最大積雪深は $48 \mathrm{~cm}$ で (Fig. 13 参照)、 冬期平均気温が解析を行った 20 年分の中で最も高かった (Fig.14
参照)。気温が高いことで湿り雪となり、各層の含まれる水当量が推 定值より高く、例外となる大きな誤差を招いたと考えられる。

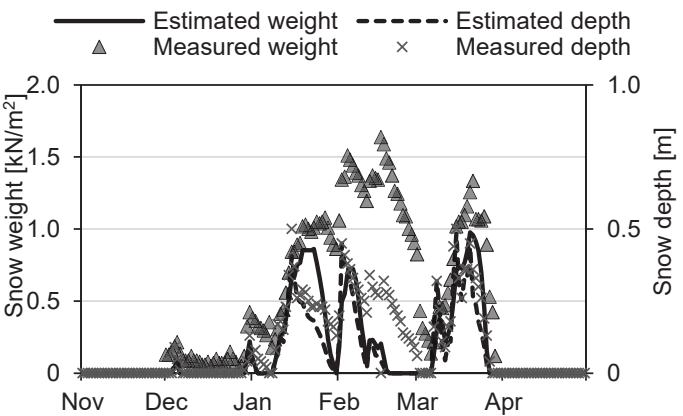

Fig.13 Snow weight and snow depth in Shinjo in 2006/2007.

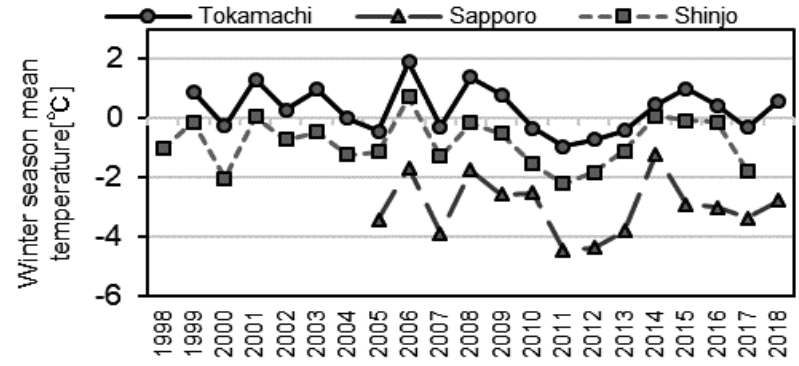

Fig.14 Winter season`s average temperature in each location 


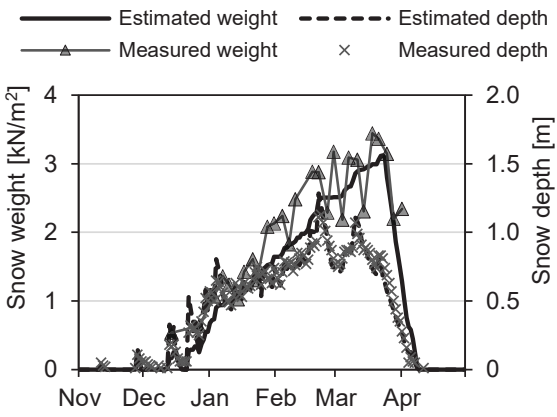

a. Snow weight and snow depth transition in $2013 / 2014$

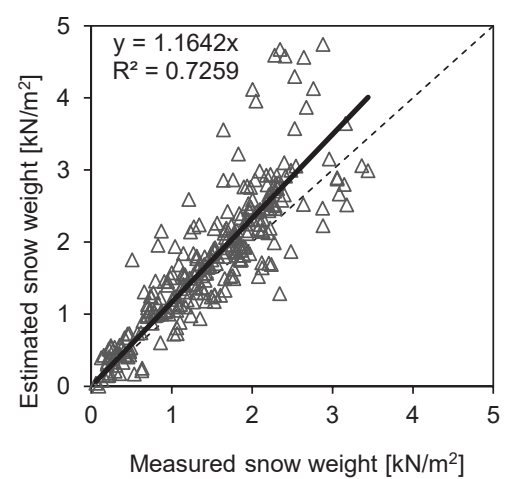

b. Comparison of Estimated weight and Measured weight of 10 years

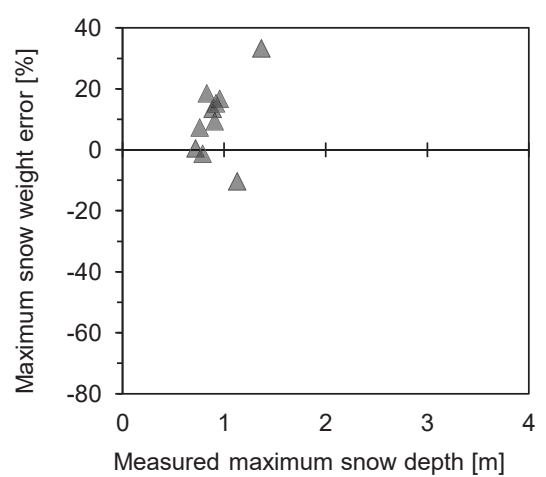

c. Max snow weight error and Measured max snow depth relation of $10 y e a r s$

Fig.15 Analysis result of Daily snow layer model in Sapporo

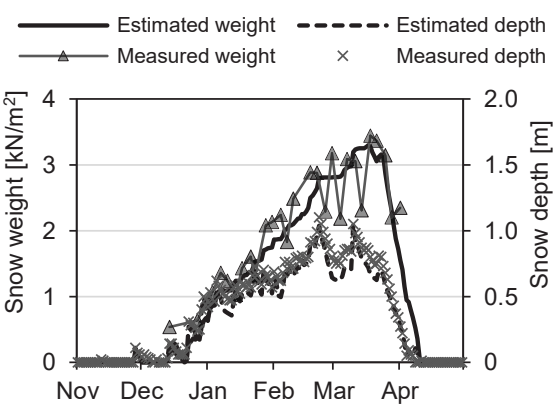

a. Snow weight and snow depth transition in $2013 / 2014$

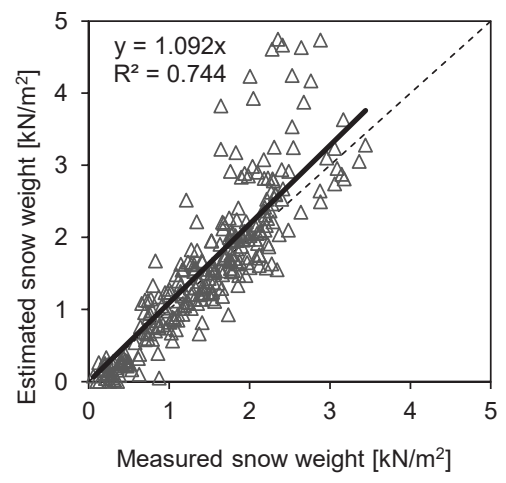

b. Comparison of Estimated weight and Measured weight of 10 years

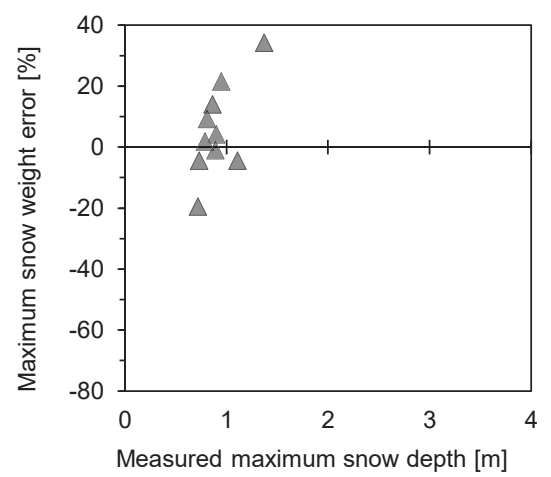

c. Max snow weight error and Measured max snow depth relation of 10 years

Fig.16 Analysis result of Hourly snow layer model in Sapporo

\section{3 札幌での解析結果}

札幌での高橋モデルの推定結果を Fig.15 に, リアルタイム推定の 推定結果を Fig.16 に示す。ただし、14 冬期分の解析を行ったが、 手元にある積雪重量データが 10 冬期分しかなかったため、比較は 10 冬期とした。

Fig.15.a と Fig.16.a では推定精度のよかった 2013/14 冬期の積雪 重量と積雪深の推移をそれぞれ示す。高橋モデルでは、積雪重量の 推移が滑らかである一方、推定值は観測值を大きく下回る傾向が見 られる。他方、リアルタイム推定による解析の結果は、全体的に推 定值は観測值より小さめだが高橋モデルより観測值に近づいており、 最大積雪重量に達する時期が観測值と一致している。

Fig.15.b と Fig.16.bには縦軸に推定積雪荷重、横軸に観測積雪重 量を取った 10 年分の観測值と推定值の比較分布図を示す。札幌で の解析結果は高橋モデルとリアルタイム推定が共に、3 地点の中で 最も精度が低い。その原因の一つとしては北海道大学低温科学研究 所で測定された值に誤差が生じているためと推察されるが、これに ついては、 5.4 節で詳しく述べる。

Fig.16.b から分かるように、札幌での傾きは最も大きく 1.092 と なった。その原因の一つとしては Fig. 5 の札幌の冬期最適化パラメ ータのばらつきが大きいためであると考えられる。札幌の地点最適 化パラメータは 14 年分の冬期最適パラメータの平均值であるため、
2 つのパラメータが大きくかけ離れたことで、誤差が大きくなった 可能性がある。

さらに高橋モデルと比較してリアルタイム推定では、回帰直線の 傾きや決定係数 $\mathrm{R}^{2}$ は改善されたが、新庄と十日町と比較して分布は 広がっており、ばらつきが大きい。また新庄や十日町の傾向と異な り、積雪重量が低いときは精度が良いものの、積雪重量が増加する と精度が悪くなる傾向が見られた。

Fig.15.c と Fig.16.cには 10 年間分の実測の最大積雪深に対する 推定值と観測值の最大積雪重量の誤差の関係を示す。解析対象とな った 10 年間の最大積雪深のばらつきが小さいものの、誤差は大き く異なり、高橋モデルの方がリアルタイム推定より、誤差の広がり が小さいように見える。

また札幌の 2012/13 冬期では、積雪深を見ると実測と推定で完全 に雪が無くなる時期にずれが生じている (Fig.17参照)。これは解析 による春先の融雪量が実際に比べて少ない事が原因であると考えら れる。そのため 3 月頃の融雪係数は地点最適化パラメータで設定し た值よりも大きい值とするなど、融雪係数を時期に応じて使い分け ることが必要であると考えられる。これにより消雪時期が一致し、 推定精度が向上する可能性がある。

一方で Fig.17 と Fig.18 を見ると、2 月中旬頃からの降雨による 積雪重量の増加は推定値で過大に降水を保持しているような傾向が 
見られた。この結果より 2 月中頃から 3 月頃の積雪層の雪質は、圧 密や降水の浸透によって解析よりも早くザラメ雪に変化し、実際は 降雨や融雪水は保持されずに積雪底面から流出している可能性があ る。また札幌では気温が低く融雪下限気温の $-2^{\circ} \mathrm{C}$ を回る日も多い。 このときモデル上では融雪は全く起こらないが、気温が低い場合で も晴れて日差しがあれば日射によって融雪が起こる事が考えられる。 積雪重量が正確な値であるならば、これらを考慮できていない事が 過大推定となった原因の一つであると考えられる。

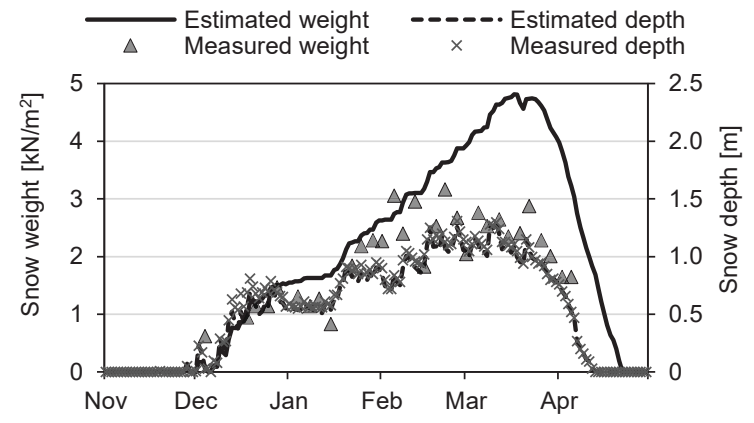

Fig.17 Snow weight and snow depth in Sapporo in 2012/13.

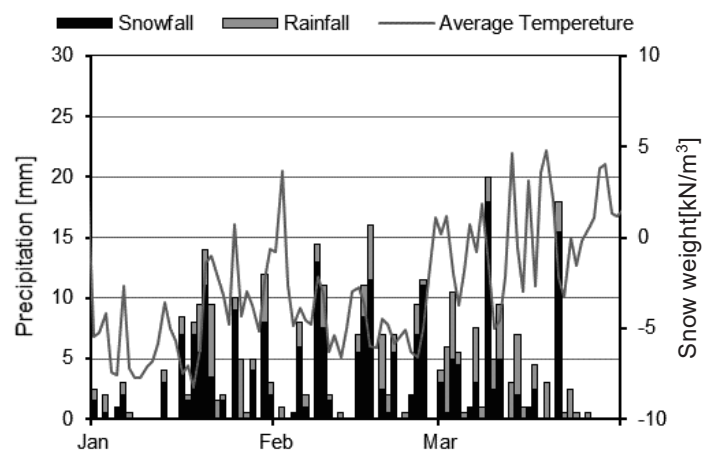

Fig.18 Snowfall, rainfall and average temperature of Sapporo in 2012/13.

\section{4 北海道大学低温科学研究所での測定方法}

Fig. 17 の 2 月から 3 月にかけて積雪重量と観測值の推移を見てみ ると、積雪深が大きく減少したことがあまり見られないにも関わら ず、積雪重量だけを見ると 3 回も大きく増減している。その原因と しては北海道大学低温科学研究所での積雪重量の測定結果にばらつ きが生じている可能性がある。

2.2 節で述べた通り北海道では週に 2 回、断面観測の単位体積重 量の測定をしている。Fig.19 は積雪の断面図である。北海道大学低 温科学研究所では一定の高さ毎に単位体積重量の測定を行い、等価 単位重量を計算している。積雪重量はこの等価単位重量と積雪深の 積で求めているため、積雪層が複雑になるほど等価単位重量の計算 に誤差が生じ、結果として積雪重量の誤差が大きくなると推察され る。このため実測值が大きく増減し、推定の精度が下がったように 見えると考えられる。

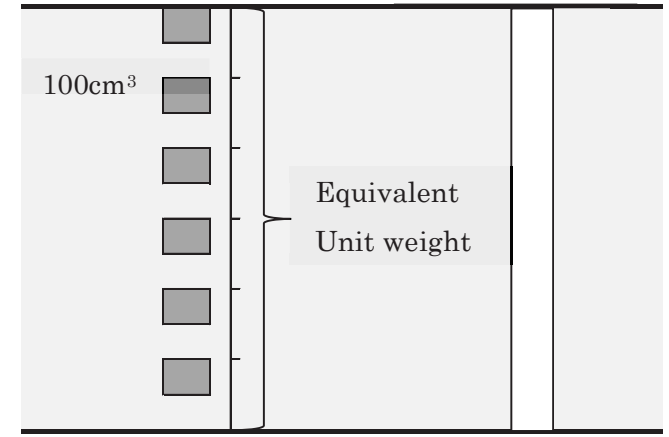

Fig.19 Measuring method of snow weight in Hokkaido University.

\section{6. 結論}

本研究から以下のことがわかった。

1. 地点最適化パラメータを新たに導入することでリアルタイム 推定が可能となった。

2. 1 時間ごとの記録データを解析に用いることによって、全体的 に高橋モデルより推定精度を上げることができた。

3. 高橋モデルで、捕捉率補正を行うと、地点によっては回帰直線 の傾きが大きくなり、推定精度を下げるため、今後再検討が必 要である。

4. 観測と推定の積雪深が完全に無くなる時期がずれる場合が多 いことから、リアルタイムで一致させるためには融雪係数を 1 冬期に通じて同じ值を使用するのではなく、融雪係数を時期に 応じて使い分ける必要がある。

\section{謝辞}

本稿では新庄と札幌の気象観測記録は AMeDAS の観測記録を使用 させて頂きました。推定積雪重量の精度検証にあたり積雪重量の観 測記録は、新庄では防災科学技術研究所雪水防災研究センターで公 開しているデータを使用させて頂き、札幌では北海道大学低温科学 研究所と気象庁気象研究所との共同研究 (気象庁気象研究所に配分 された環境省地球環境保全等試験研究費、及び北海道大学低温科学 研究所一般共同研究 (19G036)) にて取得されたデータを、十日町で は森林総合研究所十日町試験地の竹内由香里博士に観測記録をそれ ぞれ提供して頂きました。また本研究の一部には、新潟大学災害・ 復興科学研究所共同研究費（2019-10）の助成を受けました。ここに 記して感謝致します。

\section{参考文献}

1) Architectural Institute of Japan: Recommendations for Loads on Buildings (2015), 2015

日本建築学会：建築物荷重指針・同解説 (2015), 2015

2) SAKURAI Shuji, JOH Osamu: Estimation of Ground Snow Weights Based on the Data of Daily Precipitations and Daily Mean Air Temperatures - Influence of Limit Air Temperature to the Error of Estimation -, Summaries of Technical Papers of Annual Meeting, Architectural Institute of Japan, B-1, pp. 91-92, 1995. 7 桜井修次, 城攻：累積降水量に基づく地上積雪重量の推定-推定に及 ぼす判別気温の影響について-, 日本建築学会大会学術講演梗概集, 
B-1, pp. 91-92, 1995. 7

3) SAKURAI Shuji, JOH Osamu: Estimation of Ground Snow Weights Based on the Data of Daily Precipitations and Daily Mean Air Temperatures, Summaries of Technical Papers of Annual Meeting, Architectural Institute of Japan B-1, pp. 75-76, 1995. 7 桜井修次, 城攻：気温、降水量資料に基づく地上積雪重量の推定に関 する考察，日本建築学会大会学術講演梗概集, B-1, pp. 75-76, 1995. 7

4) KAMIMURA Seiji, UMEMURA Teruyoshi: Estimation of Daily Snow Mass on the Ground Using Air Temperature and Precipitation Data, Second International Conference on Snow Engineering, CREEL Special Report 92-97, pp. 157-167, 1992

5) KAMIMURA Seiji: Improvement of Snow Weight Estimation Formula Using Daily Temperature and Precipitation Data, Proceedings of The Japanese Society of Snow and Ice, p. 162, 1995 上村靖司: 日気温、降水量データによる積雪重量推定式の改良, 日本 雪水学会大会講演予稿集,p. 162, 1995

6) KAMIMURA Seiji, UMEMURA Teruyoshi: A Proposal Effective Design of Snow-melting System, Journal of Snow Engineering of Japan, Vol. 12, No. 3, pp. 212-217, 1996

上村靖司，梅村晃由：屋根融雪装置の能力設計に関寸る提案，日本 雪工学会誌, Vol. 12, No. 3, pp. 212-217, 1996

7) KURAMOTO Koji, TAKAHASHI Toru: Estimation of snow load using rainfall data, Summaries of Technical Papers of Annua Meeting Architectural Institute of Japan, B-1, pp. 81-82, 1996. 7 倉本幸治, 高橋徹：降水量データによる積雪重量の推定, 日本建築 学会大会学術講演梗概集, B-1, pp. 81-82, 1996. 7

8) KURAMOTO Koji, TAKAHASHI Toru: Estimation of Ground Snow Load Using Snow Layer Model Part1. Part2, Summaries of Technical Papers of Annual Meeting, Architectural Institute of Japan, B-1, pp. 107-110, 1997. 7

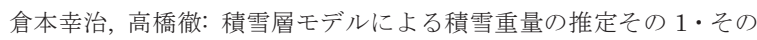
2, 日本建築学会大会学術講演梗概集, B-1, pp. 107-110, 1997. 7

9) TAKAHASHI Toru, KAWAMURA Taiki, KURAMOTO Koji: ESTIMATION OF GROUND SNOW LOAD USING SNOW LAYER MODEL, Journal of Structural and Construction Engineering (Transactions of AIJ), No. 545, pp. 35-41, 2001. 7 高橋徹, 川村大樹, 倉本幸治: 積雪層モデルによる地上積雪荷重の 推定, 日本建築学会構造系論文集, 第 545 号, pp. 35-41, 2001. 7

10) HIRASHIMA Hiroyuki, YAMAGUCHI Satoru, KOSUGI Kenji, NEMOTO Masaki, AOKI Teruo, MATOBA Sumito: Validation of the SNOWPACK model using snow pit observation data, Journal of the Japanese Society of Snow and Ice, Vol. 77, No. 1, pp. 5-16, 20151

平島寛之, 山口悟, 小杉健二, 根本征樹, 青木輝夫, 的場澄人：断面 観測結果を用いた積雪変質モデルの検証, 日本雪水学会誌雪水, 77 巻 1 号, pp. 5-16, 2015. 1

11) Japan Meteorological Agency: Download past weather data, https://www.data.jma.go.jp/gmd/risk/obsdl/index.php, (accessed 2020-01-06)

気象庁：過去の気象データ・ダウンロード,

https://www.data.jma.go.jp/gmd/risk/obsdl/index.php,

(参照 2020-01-06)

12) TAKEUCHI Yukari, KATSUSHIMA Takafumi, ENDO Yasoichi: Data of meteorology and snow pit observations at Tohkamachi Experimental Station, Forestry and Forest Products Research Institute, Japan(IX) (2014-15 to 2018-19, five winter periods), Bulletin of FFPRI, Vol. 18-No. 4 (No. 452), pp. 393-443, 2019. 12
竹内由香里, 勝島隆史, 遠藤八十一: 森林総合研究所十日町試験地 における冬期の気象及び雪質の調查資料(9) (2014/2015 年 2018/195 冬期), 森林総同研究所研究報告, Vol. 18-No. 4 (No. 452), pp. 393-443, 2019. 12

13) National Research Institute for Earth Science and Disaster Resilience: Meteorological, Snowfall and Snow Cover Data Observed at Shinjo (2017/18 Winter), Technical Note of the National Research Institute for Earth Science and Disaster Resilience, No. 433, 2019. 3

防災科学技術研究所：新庄における気象と降積雪の観測（2017/18 冬期)，防災科学技術研究所研究資料，第 433 号, 2019.3

14) Aoki Teruo, Niwano Masashi, Matoba Sumito: Snow observations and development of physically based process model at Sapporo, Low Temperature Science, No. 74, pp. 163-174, 2016 青木輝夫, 庭野匡思, 的場澄人：札幌における積雪観測と物理プロ セスモデル開発, 低温科学, 74 巻, pp. 163-174, 2016

15) YOKOYAMA Kotaro, OHNO Hiroyuki, KOMINAMI Yasuhiro, INOUE Satoshi, KAWAKATA Toshikazu: Performance of Japanese precipitation gauges in winter, Journal of the Japanese Society of Snow and Ice, Vol. 65, No. 3, pp. 303-316, 2003

横山安太郎, 大野宏之, 小南靖弘, 井上聡, 川方俊和 : 冬期における 降水量計の補足特性, 日本雪水学会誌, 第 65 巻 3 号, pp. 303-316, 2003

16) Japan Meteorological Agency: List of weather stations, https://www.jma.go.jp/jma/kishou/know/amedas/ame_master.pdf, (accessed 2019-12-26) 気象庁：気象観測所一覧 [PDF 形式], https://www.jma.go.jp/jma/kishou/know/amedas/ame_master.pdf, (参照 2019-12-26) 


\title{
REAL-TIME ESTIMATION OF GROUND SNOW LOAD USING SNOW LAYER MODEL
}

\author{
Dai KOMIYAMA ${ }^{* 1}$, Ashidmaa BATSUURI ${ }^{* 2}$ and Toru TAKAHASHI ${ }^{* 3}$ \\ ${ }^{* 1}$ Nishimatsu Construction Co., Ltd., M.Eng. (Former Grad. Student of Chiba Univ.) \\ *2 Grad. Student, Graduate School of Science and Engineering, Chiba University \\ ${ }^{* 3}$ Prof., Graduate School of Engineering, Chiba University, Dr.Eng.
}

We proposed a real-time estimation model based on the method of Takahashi model to understand the snow weight changes during every moment of snow season. This method uses Takahashi model, which is made up from three sub models, snowfall model, compaction model, and snow melting model. In addition, the hourly snow layer model and optimized parameter for each location have been newly introduced to real-time estimation.

In hourly snow layer model, snow layer is formed by weather observation records obtained hourly from AMeDAS. The density at the hourly layer formation was calculated by the snowfall model. In addition, since it was assumed that the hourly layer was transitioning to the daily snow layer, only the infiltration of snowmelt water and rainfall was considered, while consolidation was not.

The optimized parameters for each location are average values of several years of pre-calculation result of each location. However, in the analysis using these parameters, when the value is significantly different from the average year, the error might be large. In that case, if overestimation was occurred, consolidation was forcibly performed, and if underestimation occurs, the capture rate was corrected.

The estimation accuracy was verified using this model. This paper covered Tokamachi, Shinjo, and Sapporo. The snow weight data used to compare calculation result were the observed record in Tokamachi and Shinjo, and for the Sapporo's case, the value was calculated from the record of the cross-section observation, which was done twice a week. Also, the comparison of snow weight in the verification was based on daily data.

In Tokamachi and Shinjo, the estimation results were sometimes low in the winter with little snow, they were almost accurate in the winter with a lot of snow. In Sapporo, although they were accurate in some winters, the error of the maximum snow weight was over $30 \%$ in winters with a lot of snow.

In Sapporo in the winter of 2012/13, the obtained value by cross-section observation might be inaccurate and the snow weight might be less than the true value. On the other hand, the increase in snow weight due to rainfall from mid-February might be indication that the estimated layer is overly absorbing precipitation. Therefore, the actual snow conditions of the snow layer from mid-February to March is possibly changing to granular snow earlier than our estimation due to consolidation and precipitation infiltration, rainfall. In result snowmelt water and rainfall may not be retained and flowed out from the bottom of the snow. In addition, the temperature in Sapporo is extremely low in winter, so there are many days when the temperature drops below $-2^{\circ} \mathrm{C}$, which is set as the minimum snowmelt temperature. At this time, snow melting does not occur in the analysis, but there is a possibility that snow melting might occur due to solar radiation. If snow weight measurements are accurate, one of the factors might lead to overestimation since these mechanisms were not considered in our estimation

Furthermore, there was a gap between the estimated values and measured values when the snow melted completely in the winter of 2012/13 in Sapporo. Since the gap was caused by the fact that amount of estimated snowmelt in early spring might be smaller than the actual one, it may be necessary to use different parameters depending on the season. 